\title{
LANGUAGE EDUCATION AS A STATE, SOCIAL AND PERSONAL VALUE AT THE PRESENT STAGE OF SOCIAL DEVELOPMENT
}

\author{
D.U. Rasulova \\ Senior teacher Department "Languages" \\ Tashkent state agrarian university, Tashkent, Uzbekistan \\ E-mail: dilfuza.rasulova72@mail.ru
}

\begin{abstract}
The article discusses the goals and objectives of teaching a foreign language at university education in the light of the requirements for the level of communicative competence determined by the educational standard of general education, the problem of language education of students in the light of changes in the educational system of our country, the general state of language education at this stage. The features of a personality-oriented approach to teaching and upbringing of students are being formed.
\end{abstract}

Key words: language education, skills and abilities, teaching foreign languages, state value as a social value, personal value.

\section{Introduction}

Recently, the term "language education" has been used quite often, but at the same time, there is no common point of view on its content among scientists and practitioners. Language education is often understood as the process of assimilating systematized knowledge, skills and abilities that allow one to carry out foreign language speech activity. In other cases, language education is interpreted as a result of this process or as a system of educational institutions in which non-native languages are taught. blocks:

If we accept B.S. Gershunsky, then language education as a value involves the consideration of three axiological

1. Language education as a state value;

2. Language education as a public value;

3. Language education as a personal value.

We note right away that we are talking about interconnected blocks. Only in the harmony of state, public and personal interests in the development of language education in the country, giving it priority importance at all levels under consideration, it is possible to achieve high-quality results in solving not only the socio-pedagogical problems facing society, the state, but also social and cultural problems. Awareness of language education as a value determines the relevance of the development and implementation of scientific and practical actions related both to the analysis of the attitude of the state, society and the individual towards it, and to ensuring the prestige of this education at the publicstate and personal levels. The role of any language is determined by its status in society, the state. Language can be an international medium of communication.

\section{Main part}

First of all, we are talking about the languages of global distribution and common human culture, which perform the maximum amount of social functions. These languages include, for example, English, Russian and French. If a language is spoken in a number of countries of a particular region, this language acquires the status of an interstate one.

Language can also play the role of a state or local language. The first languages include, for example, the Uzbek language in our country, which is the official means of interethnic communication, and the second - any language used in a particular region or district of a particular country. It is quite obvious that from the point of view of the formation of the value orientations of a particular person in the modern world, the expansion of his educational and social capabilities, the languages of global communication are the most significant. But this thesis does not mean that along with the languages of international communication, local languages should not be studied and that the state and society should not create favorable conditions for this. As you know, the state and society are not identical concepts. Society may need to learn modern non-native languages. For example, the everyday reality of recent years testifies to the increased status of foreign languages in society.

Today, no one doubts the fact that the dynamics of the country's social life and the new goals, scale and direction of transformations associated with it cause a public need for a large number of citizens who practically speak one or several modern non-native languages. Knowledge of languages, and especially languages of international importance, as a rule, gives an individual the opportunity to get real chances to occupy a more prestigious position in society, both socially and financially. Moreover, the fact that human resources become the wealth of society in the conditions of a modern market economy and the development of information technologies, which act as the main strategic factor of economic and social progress, is becoming increasingly recognized. In solving this problem, an important role is assigned to language education as a factor that turns a person into a developed personality and expands his social and 
economic freedom. Some methodologists distinguish between a linguistic model and its speech embodiment - speech models. [1] world are:

Among the most important circumstances testifying in favor of the demand for foreign languages in the modern

1) globalization of integration social processes;

2) interstate integration in the field of education;

3) access to experience and knowledge in the world, to great information wealth, to quality education in the country and abroad.

The actualization of proficiency in a professional language in the academic environment is due to a number of reasons: the possibility of international professional contacts, internships, tests, international cooperation, as well as the desire to master professional literature and publish abroad. Students studying a professional language at a university are distinguished by a very high degree of motivation, as they see real prospects for using such a language in their professional activities. [2]

Socio-political and economic realities of social development affect not only the status of modern non-native languages, including foreign languages, but also the functions they perform in society. Today these functions in the social plane can be formulated as follows: the establishment of mutual understanding between peoples-carriers of different languages and cultures; providing access to the diversity of world politics and culture, including through the means of new information technologies. Language, and hence language education, is an important tool for the successful life of a person in a multicultural and multilingual community of people. Indeed, at the present stage of the country's development, a stage characterized by deep integration processes in all spheres of public life, language education acts as a significant medium, it forms the consciousness of an individual, his ability to be socially mobile in society, freely "enter" the open information space. Even under favorable conditions, the state and social significance of language education should be supported by its personality-oriented value. The latter is associated with the individually motivated and stimulated attitude of an individual to his own education in general and language education in particular, to its level and quality.

The personality-oriented value of language education is due to:

a. The degree of students' awareness of the importance of any non-native language as a means of communication in the modern multilingual and multicultural world;

b. A clear idea of the requirements that are imposed on the level of his language training at each educational stage, and the technologies that make it possible to determine this level;

c. Personal need for the study of modern non-native languages and their practical use. It is the last parameter, and not the legal status of a particular language, that determines the prestige of the language and language education in general for a particular person.

In turn, at the state-social level, the prestige of language education depends on the degree and depth of intercultural integration in specific geopolitical regions, the range of political, economic and cultural needs in international cooperation and interethnic cooperation. The creation of such conditions in society will make it possible to establish ways of reasonably satisfying social, state and personal needs and interests in the study of modern non-native languages and to formulate a social order, i.e. requirements of the state and society for the linguocultural training of students. The social order is designed to harmonize state, social and personal needs in relation to modern non-native languages. Since, as noted above, in the socio-political, economic, ethnocultural context of development, knowledge of languages becomes a necessary part of a person's personal and professional life, the requirements of the state and society to the results of linguocultural training of students should be expressed in the ability of the latter to use the languages being studied in real intercultural communication. Linguistic diversity and cultural diversity are currently considered as one of the most valuable elements of the world, European and all-Uzbek cultural heritage and as a philosophy of intercultural social interaction in any polycultural and multilingual space.

\section{Conclusion}

The political sphere is also increasingly aware of the fact that the diversity of linguistic communities and cultures, being an invaluable unique heritage, in the future should turn from a factor that hinders dialogue between representatives of different cultures into a means of mutual understanding and enrichment.

\section{References}

1. Bakirova H.B. Teaching foreign language terminology at non-language universities. International journal of discourse on innovation. Integration and education. Volume: 01 Issue: 01.2020 http://summusjournals.uz/index.php/ijdiie

2. Bakirova H.B. Formation of terminological competence in ESP education. Novateur publications. Journal NX- A Multidisciplinary Peer Reviewed Journal, ISSN No: 2581 - 4230 VOLUME 6, ISSUE 11, India.-2020. P 63. 